\title{
BAZAR ILMU DENGAN METODE MIND MAP DI TANAH OMBAK
}

\author{
Romi Isnanda ${ }^{1}$, Witri Anisa ${ }^{2}$, dan Rio Rinaldi ${ }^{3}$ \\ Program Studi Pendidikan Bahasa dan Sastra Indonesia \\ FKIP, Universitas Bung Hatta \\ 1e-mail: isnanda.romi@yahoo.com
}

\begin{abstract}
Abstrak
Tujuan kegiatan adalah sebagai salah satu kegiatan yang dapat meningkatkan minat baca adalah membudayakan kegiatan literasi di kalangan anak-anak. Kegiatan literasi dilakukan dengan metode mind map. Bazar ilmu dilaksanakan dengan memberikan latihan-latihan yang kontiniu sebagai persiapan anak-anak mengahadapai ujian akhir semester atau ujian akhir nasional. Kegiatan dilaksanakan di Komunitas Tanah Ombak dengan pendekatan Quantum Learning dengan metode mind map. Berdasarkan pelaksanan pelatihan penjelasan materi dan pembahasan soal ujian yang terdapat dalam program bazar ilmu dengan metode mind map di Tanah Ombak, dapat disimpulkan, yaitu (1) melalui program bazar ilmu dengan metode mind map memberi kebebasan kepada anak untuk membahas dan mepertanyakan kepada instruktur tentang sisi kesulitan yang mereka rasakan sehingga proses pembelajaran lebih santai karena anak-anak tidak merasa terbebani; (2) konsep pembelajaran "belajar sambil bermain" juga terintegrasi selama proses pelatihan berlangsung; (3) melalui program kegiatan bazar ilmu dengan menggunakan metode mind map juga berdampak pada perolehan nilai siswa ketika menjawab soal-soal yang diberikan setelah penjelasan materi. Hal tersebut disebabkan adanya iklim pembelajaran yang sangat santai dan siswa tidak merasa terbebani dalam pembelajaran.
\end{abstract}

Kata kunci: bazar, ilmu, mind map, Tanah Ombak

\begin{abstract}
The purpose of the activity is as one of the activities that can increase reading interest is to cultivate literacy activities among children. Literacy activities are carried out by mind map method. The science bazaar is carried out by providing continuous training in preparation for children facing the final semester exam or the final national examination. The activity was carried out in the Ombak Tanah Community with a Quantum Learning approach with the mind map method. Based on the training of material explanation and discussion of exam questions contained in the science bazaar program with the mind map method in Waves, it can be concluded, namely (1) through the science bazaar program with mind map methods giving children freedom to discuss and ask instructors about the the difficulties they feel so that the learning process is more relaxed because children do not feel burdened; (2) the concept of "learning while playing" learning is also integrated during the training process; (3) through the science bazaar activity program using the mind map method also impacts on the acquisition of student grades when answering questions given after the material explanation. This is due to the existence of a very relaxed learning climate and students do not feel burdened in learning.
\end{abstract}

Keywords: bazaar, science, mind map, Waves 


\section{PENDAHULUAN}

Bangsa yang berkualitas dapat dilihat dari sumber daya manusia yang dimiliki. Indonesia sebagai negara yang kaya dengan sumber daya alam, tetapi masih rendah dari segi kualitas sumber daya manusia. Tingkat kualitas sumber daya manusia dapat dihitung dari Indeks Pembangunan Manusia (IPM) atau Human Development Index (HDI).

Berdasarkan data BPS tersebut, pengukuran kualitas sumber daya manusia berguna untuk mengetahui keberhasilan pembangunan dari segi pendapatan, kesehatan, pendidikan. Salah satu faktor penyebab rendahnya IPM Indonesia adalah rendahnya kualitas pendidikan. Melalui pendidikan, penguasaan ilmu pengetahuan dapat diperoleh. Salah satu cara menambah pengetahuan adalah dengan banyak membaca. Membaca dapat menambah wawasan dan membuka pikiran untuk maju dan keluar dari zona kemiskinan menuju kehidupan yang sejahtera. Namun, tingkat kebiasaan masyarakat Indonesia masih rendah karena minat baca yang juga rendah. Berdasarkan data BPS tahun 2012, diketahui 91,68\% penduduk Indonesia usia 10 tahun ke atas lebih suka menonton TV dan hanya 17,66 \% yang senang membaca (Imansyah, 2016). Selain itu, prestasi akademik dalam pendidikan formal juga penting dan dapat diketahui melalui evaluasi pada ujian akhir semester atau melalui ujian nasional yang dapat ditunjang dari kegiatan membaca.

Salah satu kegiatan yang dapat meningkatkan minat baca adalah membudayakan kegiatan literasi dikalangan anak-anak. Kegiatan literasi dilakukan dengan metode mind map. Selain budaya literasi, prestasi akademik juga hal penting yang harus diperhatikan. Salah satu kegiatan yang dapat meningkatkan prestasi akademik anak-anak dan remaja adalah dengan belajar secara berkontiniu untuk mata pelajaran pokok di sekolah. Pembelajaran yang kontiniu tersebut dilaksanakan dengan kegiatan bazar ilmu. Bazar ilmu dilaksanakan dengan memberikan latihan-latihan yang kontiniu sebagai persiapan 
anak-anak mengahadapai ujian akhir semester atau ujian akhir nasional. Kegiatan bazar ilmu ini akan dilaksanakan di Komunitas Tanah Ombak. Bazar ilmu yang akan dilaksanakan dengan pendekatan Quantum Learning dengan metode mind map. Metode mind map diterapkan pada setiap latihan untuk setiap mata pelajaran pokok yang diujiankan.

\section{Kondisi Mitra}

Tanah Ombak merupakan sebuah komunitas atau gerakan literasi (membaca) bagi anak-anak sekitar Purus dan anak sekolah menengah di Kota Padang, Sumatra Barat. Komunitas ini dikomandoi oleh Yusrizal KW dan Suhendry. Lokasi komunitas ini di Jalan Purus III Padang Sumatra Barat. Berada di kawasan kampung nelayan dengan rumah-rumah berjubel dan kumuh itu dihuni warga yang kebiasaan buruk. Masyarakat dewasanya gemar berjudi dan mengonsumsi minuman keras, sedangkan anak-anak tumbuh di tengah caci-maki sehari-hari. Bahkan mereka sudah terbiasa "ngelem", mengisap aroma lem yang mengandung alkohol.

Awalnya, Suhendri dan Yusrizal KW ingin mengajari anak-anak itu mencintai seni. Mulai dengan belajar teater, Suhendri sebagai sutradara menggabung kepintaran mereka joged dangdut dengan gerakan dramaturgi. Yusrizal KW menyediakan buku-buku agar mereka mau membaca dan diajar menceritakan kembali. Dari jumlah kecil, akhirnya anak-anak yang lain tertarik dan bergabung. Tantangannya cukup berat, datang dari para orang tua yang merasa penghasilannya menurun. Sebab, anak-anak yang tak jelas pendidikannya itu sudah dipaksa bekerja mencari uang dengan cara apa saja.

Bulan Oktober 2015, Suhendri meminta izin kepada mertuanya yang tinggal di rumah itu agar rumahnya dijadikan sanggar. Demi tujuan baik itu, permintaan Suhendri dipenuhi. Sejak itu ada ruangan seluas 5 x 7 meter dijadikan tempat serbaguna. Merapat ke dinding terdapat rak-rak buku. Di dinding yang lain tertempel beberapa lukisan anak-anak itu. Perlahan-lahan perilaku anak-anak itu berubah positif. Kebiasaan berucap kotor dan berkelahi antarmereka berkurang bahkan dalam setahun berganti dengan kekerabatan dan berlaku sopan, saling 
menghormati. "Ada 4 syarat untuk bergabung ke Tanah Ombak," ujar Suhendri. "Pertama, tidak boleh berbicara kasar. Kedua, dilarang main fisik. Ketiga, harus menjaga kebersihan sanggar dan lingkungan. Keempat, belajar menyimak materi dan menceritakan kembali."

Komunitas Tanah Ombah menyediakan sarana perpustakaan. Menurut Yusrizal KW, di perpustakaan Tanah Ombak terdapat sekitar 3000-an buku merupakan koleksi pribadi dan sumbangan dari berbagai pihak. Koleksi tersebut terdiri atas $80 \%$ buku fiksi anak, $10 \%$ buku fiksi dewasa, dan $20 \%$ buku nonfiksi. Namun, buku-buku tersebut belum tersusun rapi di komunitas tanah ombak.

Dengan disediakannya sarana perpustakaan di Tanah Ombak, anak-anak bisa membaca secara bebas. Akan tetapi, banyak anak yang membaca hanya untuk bermain. Kegiatan membaca akan lebih bermakna jika dikaitkan dengan pengetahuan sehingga dapat menunjang kemampuan akademik anak-anak Tanah Ombak. Budaya literasi yang sudah tercipta perlu dilakukan pembinaan agar terpola dan kontiniu sehingga kegiatan membaca lebih bermakna.

Komunitas Tanak Ombak sangat peduli terhadap seni dan sastra, khususnya sastra anak. Namun, kegiatan dibidang akademik tidak terlalu menonjol sehingga kurang menunjang prestasi akademik. Kegiatan yang menunjang prestasi akademik belum terkelola dengan baik sehingga hasil belajar anak-anak pun tidak terlalu menggembirakan.

Dengan berbagai permasalahan yang diuraikan sebelumnya, perlu dilakukan upaya mengatasi masalah tersebut. Upaya yang dapat dilakukan antara lain: pertama, melakukan pembinaan kegiatan membaca yang bermakna dengan menerapkan metode mind map. Strategi tersebut dilaksanakan dengan membuat peta konsep buku-buku yang telah dibaca agar mudah menyimpulkan isi bukubuku tersebut. Dengan memiliki kemampuan membaca yang baik melalui metode mind map, kualitas kegiatan membaca anak-anak di Tanah Ombak dapat lebih bermakna dan sekaligus dapat menunjang kemampuan akademik. Kedua, kegiatan bazar ilmu dengan melaksanakan pembahasan soal-soal ujian akhir semester dan soal-soal ujian, khusus mata pelajaran Bahasa Indonesia, Matematika, Bahasa 
Inggris, dan Biologi. Pelaksanaan pembelajaran pembahasan soal tersebut dilakukan dengan metode mind map.

Berdasarkan hasil kunjungan ke lokasi (Gambar 1 dan 2) dan wawancara dengan mitra tersebut (Gambar 3), beberapa permasalahan prioritas yang dihadapi oleh mitra telah teridentifikasi dan membutuhkan penanganan yang tepat dalam program PKM, yaitu: (1) belum termanfaatkan secara maksimal buku-buku di perpustakaan Tanah Ombak dan Lentera Kuning karena budaya literasi yang belum terbina dengan baik; (2) kegiatan yang menunjang prestasi akademik belum terkelola dengan baik sehingga prestasi belajar anak belum terlalu menggembirakan.

Adapun upaya menyelesaikan masalah yang dihadapi mitra seperti yang disajikan pada Tabel 1 .

Tabel 1 Rincian Kegiatan Program

\begin{tabular}{|c|c|c|c|}
\hline $\mathrm{No}$ & Masalah & Program & Solusi \\
\hline 1 & $\begin{array}{l}\text { Belum termanfaatkan } \\
\text { secara maksimal } \\
\text { buku-buku di } \\
\text { perpustakaan Tanah } \\
\text { Ombak dan } \\
\text { Komunitas Lentera } \\
\text { Kuning karena } \\
\text { budaya literasi yang } \\
\text { belum terbina dengan } \\
\text { baik }\end{array}$ & $\begin{array}{l}\text { Peningkatan } \\
\text { Budaya Literasi }\end{array}$ & $\begin{array}{l}\text { Pembinaan budaya literasi } \\
\text { melalui Quantum Learning } \\
\text { dengan metode mind map }\end{array}$ \\
\hline 2 & $\begin{array}{l}\text { Kegiatan yang } \\
\text { menunjang prestasi } \\
\text { akademik berlum } \\
\text { terkelola dengan baik } \\
\text { sehingga prestasi } \\
\text { belajar anak belum } \\
\text { terlalu } \\
\text { menggembirakan. }\end{array}$ & & $\begin{array}{l}\text { Kegiatan bazar ilmu berupa } \\
\text { latihan pembahasan materi } \\
\text { ujian akhir semester dan ujian } \\
\text { nasional untuk beberapa mata } \\
\text { pelajaran pokok, seperti } \\
\text { bahasa Indonesia, } \\
\text { matematika, dan biologi. } \\
\text { Latihan tersebut dilaksanakan } \\
\text { dengan matode mind map. }\end{array}$ \\
\hline
\end{tabular}

\section{METODE}


Metode pelaksanaan program ini menjadi dasar acuan bagi tim dalam menjalankan seluruh kegiatan yang telah ditetapkan. Oleh karena itu, dibutuhkan tahapan metode pelaksanaan yang kongkret dan tepat. Adapun tahapan prosedur tersebut antara lain:

1. Tahap persiapan. Tahapan ini diperlukan oleh tim pengusul untuk menyiapkan hal-hal apa saja yang menjadi kebutuhan pelaksanaan program. Tahapan ini diawali dengan survei dan wawancara langsung dengan masyarakat yang dalam hal ini adalah mitra 1 dan mitra 2 .

2. Tahap pelaksanaan program. Tahapan ini dilakukan berdasarkan bidang keahlian masing-masing namun tetap dalam pelaksanaannya seluruh tim terlibat.

3. Tahap evaluasi. Tahapan ini dilakukan oleh tim sebagai bentuk komitmen dalam menunjang keefektifan program. Selain itu, melalui evaluasi inilah indikator pencapaian dapat terukur.

4. Tahap pelaporan. Tahapan ini disusun oleh tim sebagai bentuk pertanggungjawaban atas usulan serta pelaksanaan keseluruhan kegiatan dalam program PKM.

5. Tahap keberlanjutan. Tahapan terakhir ini diperlukan tidak hanya oleh kedua mitra program, namun diperuntukan pula oleh tim pengusul sebagai bentuk komitmen tinggi dalam menjalankan Tri Dharma Perguruan Tinggi dalam bidang pengabdian masyarakat.

Kegiatan bazar ilmu di Komunitas Tanah Ombak, Purus, Padang dilaksanakan pada bulan Maret 2018. Bazar ilmu dilaksanakan dengan pendekatan Quantum Learning dengan metode mind map. Metode mind map diterapkan pada setiap latihan untuk setiap mata pelajaran pokok yang diujiankan. Adapun mata pelajaran yang diberi pelatihan adalah mata pelajaran Bahasa Indonesia, Matematika, dan Biologi. Pelaksanaan pelatihan ketiga mata pelajaran tersebut dilaksanakan dengan waktu yang berbeda. 
Pelaksanaan kegiatan dilakukan selama tiga kali pertemuan dengan dipandu oleh beberapa pemateri yang relevan dengan mata pelajaran dalam program bazar ilmu. Adapun rincian kegiatan dan penanggungjawab dapat dilihat pada Tabel 2.

Tabel 2 Rincian Kegiatan dalam Program Pembinaan Budaya Literasi dan Peningkatan Prestasi Akademik

\begin{tabular}{|c|c|c|c|c|c|c|}
\hline No & $\begin{array}{c}\text { Nama } \\
\text { Kegiatan }\end{array}$ & Pelaksana/Pemateri & $\begin{array}{c}\text { Penanggung } \\
\text { Jawab }\end{array}$ & $\begin{array}{c}\text { Subjek } \\
\text { Sasaran }\end{array}$ & Waktu & Keterangan \\
\hline 1 & $\begin{array}{l}\text { Pembinaan } \\
\text { Budaya } \\
\text { Literasi }\end{array}$ & 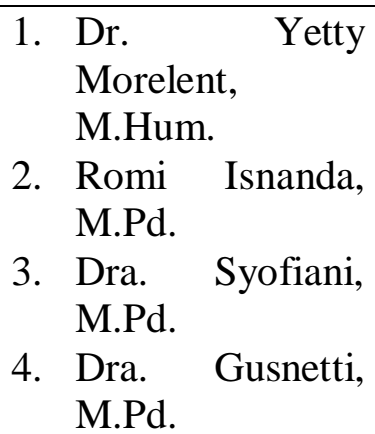 & $\begin{array}{l}\text { Dr. Marsis, } \\
\text { M.Pd. dan } \\
\text { Dr. Hasnul } \\
\text { Fikri, M.Pd. }\end{array}$ & $\begin{array}{l}\text { Anak-anak } \\
\text { dan } \\
\text { masyarakat } \\
\text { umum di } \\
\text { Tanah } \\
\text { Ombak }\end{array}$ & $\begin{array}{l}1 \\
\text { bulan }\end{array}$ & $\begin{array}{l}\text { Kegiatan } \\
\text { membaca }\end{array}$ \\
\hline 2 & $\begin{array}{l}\text { Peningkatan } \\
\text { Prestasi } \\
\text { Akademik } \\
\text { dengan } \\
\text { Bazar Ilmu }\end{array}$ & 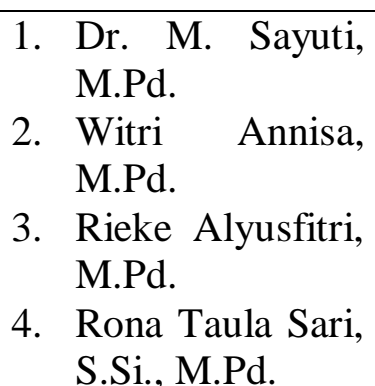 & $\begin{array}{l}\text { Dra Dainur } \\
\text { Putri, M.Pd. } \\
\text { dan Rio } \\
\text { Rinaldi, } \\
\text { M.Pd. }\end{array}$ & $\begin{array}{l}\text { Anak-anak } \\
\text { dan } \\
\text { masyarakat } \\
\text { umum di } \\
\text { Tanah } \\
\text { Ombak }\end{array}$ & $\begin{array}{l}1 \\
\text { bulan }\end{array}$ & $\begin{array}{l}\text { Latihan } \\
\text { pembahasan } \\
\text { soal UAS } \\
\text { dan UN }\end{array}$ \\
\hline
\end{tabular}

Berdasarkan uraian di atas, partisipasi mitra dalam pelaksaan program PKM adalah sebagai subjek sasaran. Pelaksanaan program akan dikontrol dan diharapkan tetap berlanjut satelah program berakhir. Untuk itu, diperlukan evaluasi pelaksanaan program agar program tersebut dapat berjalan berkelanjutan. Berikut beberapa uraian evaluasi pelaksanaan program: 
1. Pada setiap akhir bulan, tim akan melakukan evaluasi pada setiap pencapaian kegiatan. Bila belum tercapai, tim akan segera mencari solusi mengatasi permasalahan tersebut.

2. Tim pengusul akan berkomunikasi kepada kedua mitra program untuk menanyakan sekaligus menindaklanjuti jalannya program pascaprogram PKM berakhir. Jikalau ada permasalahan atau hambatan, tim pengusul akan memberikan saran dan masukan.

3. Terakhir, tim pengusul akan melakukan berdiskusi mencari solusi kongkret pada setiap hambatan dan kendala keberlangsungan program.

\section{HASIL DAN PEMBAHASAN}

Kegiatan bazar ilmu di Komunitas Tanah Ombak, Purus, Padang dilaksanakan pada bulan Maret 2018. Bazar ilmu dilaksanakan dengan pendekatan Quantum Learning dengan metode mind map. Metode mind map diterapkan pada setiap latihan untuk setiap mata pelajaran pokok yang diujiankan. Adapun mata pelajaran yang diberi pelatihan adalah mata pelajaran Bahasa Indonesia, Matematika, dan Biologi. Pelaksanaan pelatihan ketiga mata pelajaran tersebut dilaksanakan dengan waktu yang berbeda.

Teknik pembagian kelompok pada setiap mata pelajaran dilaksanakan dengan cara mengidentifikasi dan mengklasifikasi anak-anak yang merasa kesulitan dalam menjawab soal-soal ujian akhir semester dan ujian akhir nasional tiga mata pelajaran yang ditentukan. Hal tersebut menyebabkan terbentuknya kelompok-kelompok belajar yang bersifat heterogen, yaitu adanya keregaman jenjang pendidikan dan keregaman tingkat kelas. Oleh sebab itu, dalam proses pelaksanaannya dilakukan dengan cara memilih materi yang sudah dan telah dipelajari oleh anak-anak yang ada di komunitas Tanah Ombak.

Selanjutnya, proses pelaksanaan pelatihan mengarahkan anak-anak bagai mana teknik menjawab soal-soal yang lebih efektif. Hal tersebut tentunya dimulai dari proses pemahaman materi yang sudah pernah mereka pelajari, salah satunya 
dengan cara melakukan apersepsi. Anak-anak kembali diingatkan pada materi yang sudah pernah dipelajari di sekolah. Jika ada konsep yang kurang dan bahkan belum mereka pahami maka akan dibahas secara bersamaan dalam kelompok. Setelah pembahasan materi, barulah diberi soal-soal dan bagaimana teknik menjawab soal-sola tersebut.

Pertama dimulai dengan pelatihan menjawab soal-soal ujian mata pelajaran Bahasa Indonesia. Peserta yang mengikuti materi Bahasa Indonesia terdiri dari 10 orang anak dengan latar belakang jenjang pendidikan, yaitu SD, SMP, dan SMA. Pembahasan materi dan soal-soal difokuskan pada pemahaman anak-anak terhadap konsep kalimat. Pemahaman anak-anak terhadap konsep kalimat masih terkendala, siswa kurang memahami perbedaan antara frase, klausa, dan kalimat. Oleh sebab itu, anak-anak secara perlahan-lahan diarahkan untuk memahami konsep kalimat dengan cara memberi kebebasan kepada anak untuk membahas dan mepertanyakan kepada instruktur tentang sisi kesulitan yang mereka rasakan sehingga proses pembelajaran lebih santai karena anak-anak tidak merasa terbebani.

Di samping itu, konsep pembelajaran "belajar sambil bermain" juga terintegrasi selama proses pelatihan berlangsung. Hal tersebut dikarenakan instruktur mengupayakan agar proses pembelajaran tidak monoton, tanpa tekanan, dan paksakan yang mungkin dalam proses belajar mengajar di sekolah mereka rasakan. Dengan demikian, antusias anak sangat terlihat pada saat pelatihan berlangsung. Anak tidak ragu-ragu untuk mempertanyakan jika ada hal-hal yang tidak mereka pahami dan saling mendahului untuk menjawab pertanyaapertanyaan yang diberikan.

Tabel 3 Daftar Nama-Nama Peserta Pelatihan Mata Pelajaran Bahasa

\section{Indonesia}

\begin{tabular}{clc}
\hline No. & \multicolumn{1}{c}{ Nama } & Nilai \\
\hline 1. & Alya Humairah & 100 \\
\hline 2. & Putri Atika Dewi & 100 \\
\hline 3. & Rendi Ramadhan & 100 \\
\hline 4. & Arif Rahman & 100 \\
\hline
\end{tabular}




\begin{tabular}{clc}
\hline 5. & Rachel Gemi Paldika & 100 \\
\hline 6. & Rivaldo Julio & 100 \\
\hline 7. & Diva Novra & 70 \\
\hline 8. & Indah Oktavia R. & 100 \\
\hline 9. & Aina Resti F.R. & 100 \\
\hline 10. & Seni & 100 \\
\hline 11. & Gevani Aurel & 80 \\
\hline 12. & Jeni Martin & 100 \\
\hline 13. & Andri Delanda Putri & 100 \\
\hline 14. & Riska 70 & 70 \\
\hline 15. & Kurnia Ramadhani & 70 \\
\hline 16 & Shana Putri & 80 \\
\hline 17 & Maichita & 70 \\
\hline
\end{tabular}

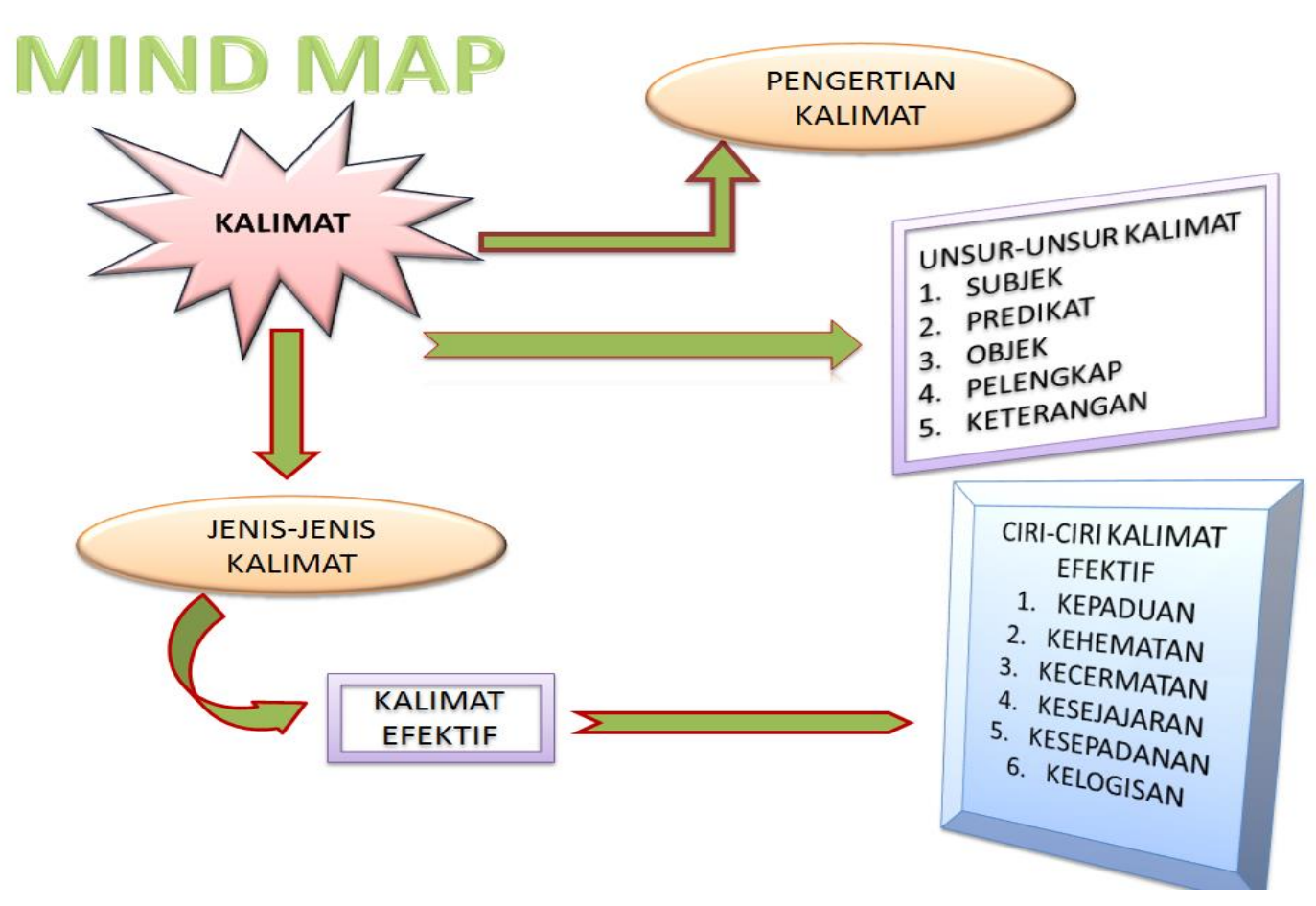

Gambar 1. Materi Bahasa Indonesia dengan Model Mind Map 


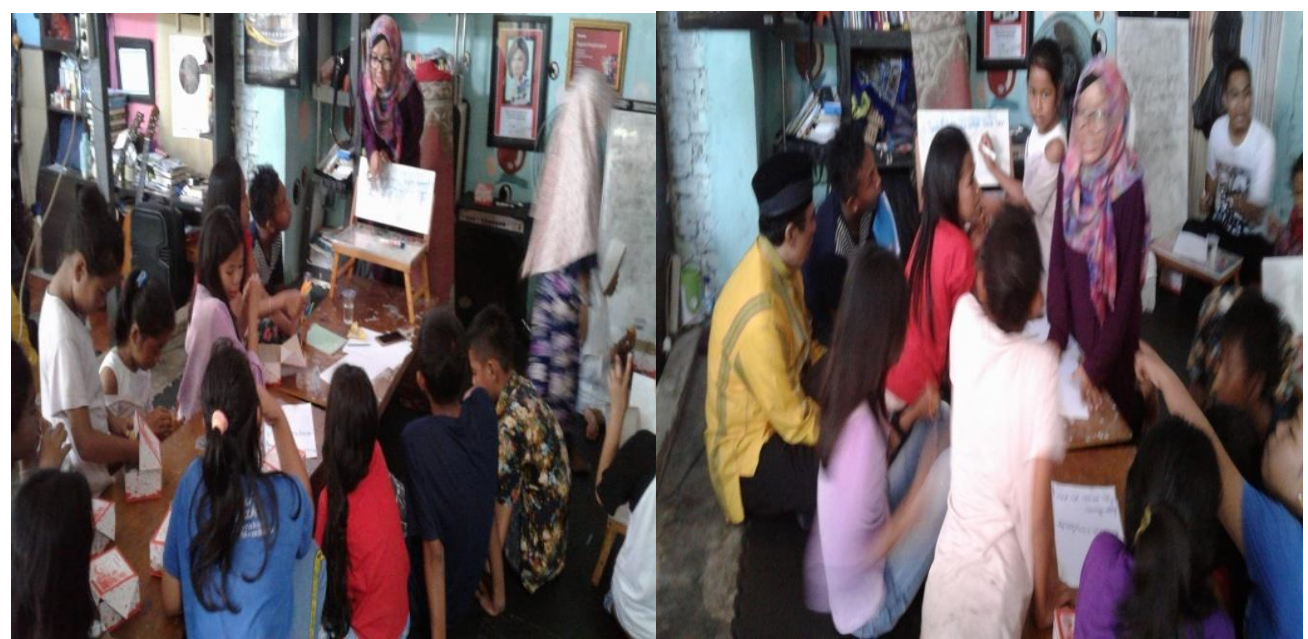

Gambar 2. Penjelasan dan Pembahasan Soal Materi Bahasa Indonesia

Kedua pelatihan menjawab soal-soal mata pelajaran Matematika. Peserta yang mengikuti pelatihan mata pelajaran Matematika terdiri dari 15 orang anak dengan latar belakang jenjang pendidikan SD dan kelas yang heterogen. Pada mata pelajaran Matematikan difokuskan pada materi perkalian, bagi, penambahan, dan pengurangan bilangan. Pada proses pelaksanaannya, instruktur memulai dengan kegiatan apersepsi agar anak dapat mengingat kembali pembelajaran yang sudah dan sedang mereka pelajari. Selanjutnya, barulah masuk pada tahapan pembahasan materi dan soal-soal ujian, baik ujian akhir semester maupun ujian akhir nasional.

Pada tahap pelatihan instruktur berupaya untuk menjelaskan materi perkalian, bagi, penambahan, dan pengurangan bilangan dengan menggunakan alat peraga yang dekat dan lazim bereda di lingkungan kehidupan anak sehingga pembelajaran lebih menarik dan berkesan bagi siswa. Adapun alat peraga yang digunakan adalah, seperti pena, permen, dan langsung menjadikan siswa sebagai subjek dari perkalian, bagi, penambahan, dan pengurangan bilangan. Hal tersebut dilakukan agar materi yang disampaikan kepada anak bisa bertahan lama dalam pemikiran anak karena dilakukan dengan cara mengaitkan dengan kehidupan nyata.

Tabel 4 Daftar Nama-Nama Peserta Pelatihan Mata Pelajaran Matematika 


\begin{tabular}{clc}
\hline No. & \multicolumn{1}{c}{ Nama } & Nilai \\
\hline 1. & Vandes Glames Yudi & 100 \\
\hline 2. & Rafa Arjuna Putri & 100 \\
\hline 3. & Ikhsan Ramadhan & 100 \\
\hline 4. & Baim & 100 \\
\hline 5. & Afgan Ardiansyah & 100 \\
\hline 6. & Fahri & 100 \\
\hline 7. & Ibrahim & 60 \\
\hline 8. & Radit Pratama & 100 \\
\hline 9. & Farel & 100 \\
\hline 10. & Bintang & 500 \\
\hline 11. & Aira Zakiah & 100 \\
\hline 12. & Kayla & 100 \\
\hline 13. & Dito & 80 \\
\hline 14. & Recha & 100 \\
\hline & & \\
\hline
\end{tabular}

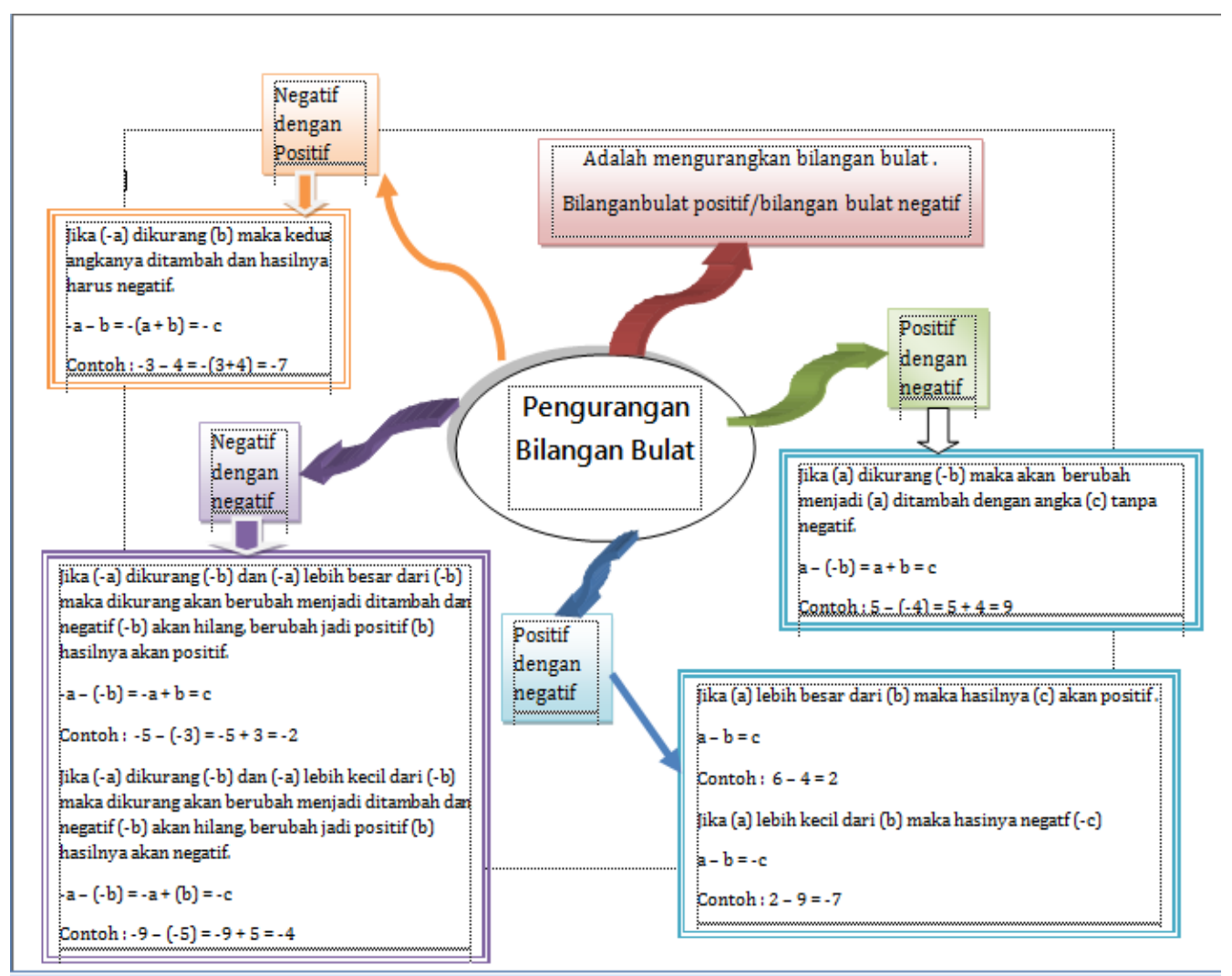

Gambar 7 Materi Matematika dengan Model Mind Map 


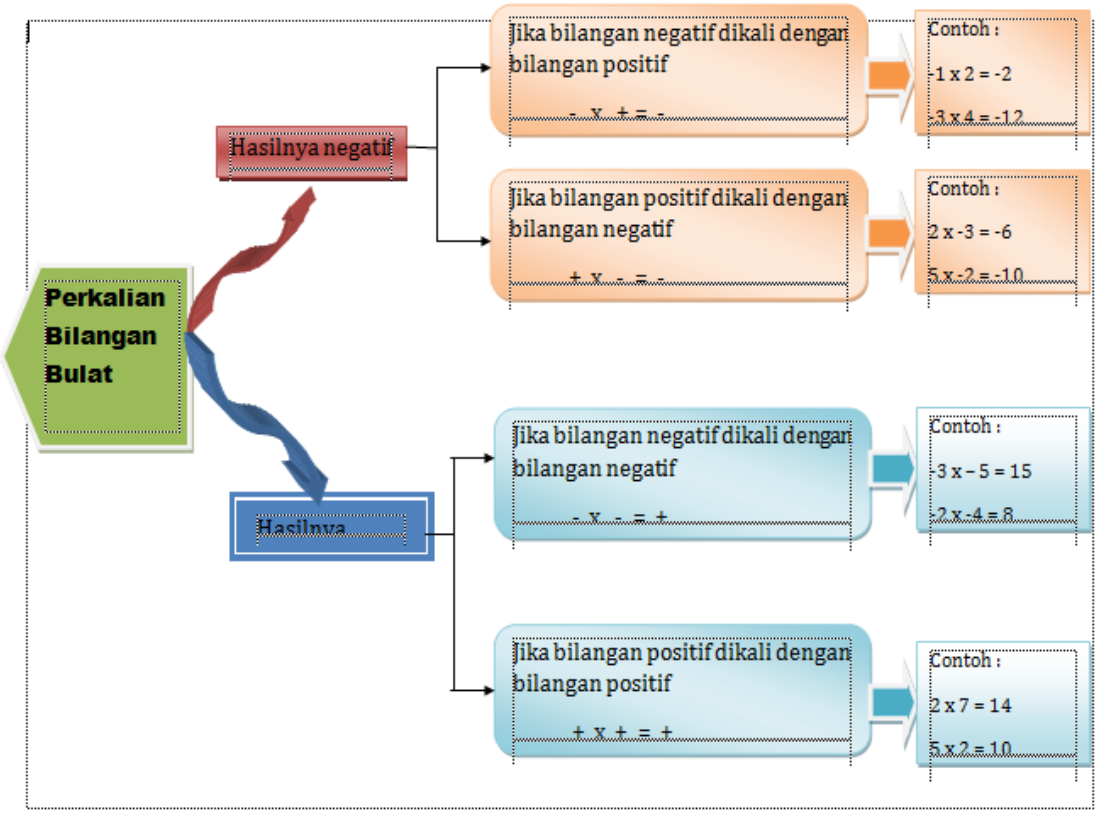

Gambar 3. Materi Matematika dengan Model Mind Map

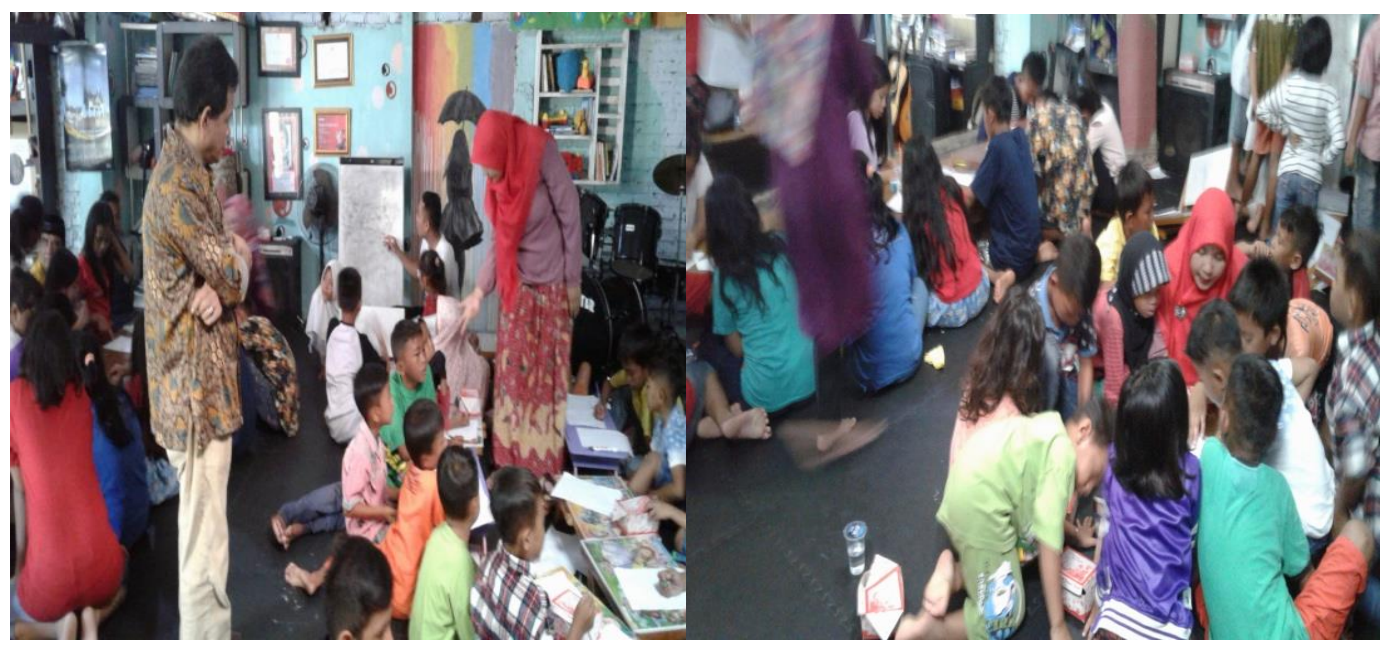

Gambar 4. Kegiatan Penyampaian dan Pembahasan Soal Matematika

Ketiga pelatihan menjawab soal-soal mata pelajaran Biologi. Peserta yang mengikuti pelatihan mata pelajaran Biologi terdiri dari 10 anak dengan latar belakang pendidikan SD dan SMP. Materi yang disampaikan lebih difokuskan pada alat pencernaan manusia. Materi tersebut sudah dan sedang diikuti oleh 
siswa. Proses penyampaian materi dilaksanakan juga dengan cara mengaitkan dengan kehidupan nyata sehingga pembelajaran lebih bermakna dan mudah diingat anak. Ketika alaur penyampaian materi dilakukan dengan cara sistematis dan terkait dengan lingkungan kehidupan maka akan memudahkan anak dalam menjawab soal-soal ujian.

Teknik penyampaian materi dilakukan dengan cara menghadirkan ke tengah-tengah anak makanan-makanan ringan dan minuman yang mengandung protein. Setelah itu, anak diminta untuk mengonsumsi makanan tersebut dan instruktur pun mengarahkan anak-anak untuk menjelaskan alur alat pencernaan manusia setelah memproduksi makanan dengan dibantu gambar alat pencernaan manusia. Langkah berikutnya, barulah anak diminta untuk menjawab soal-soal yang berkaitan dengan materi yang sudah dijelaskan sebelumnya.

Tabel 5 Daftar Nama-Nama Peserta Pelatihan Mata Pelajaran Biologi

\begin{tabular}{llc}
\hline No. & \multicolumn{1}{c}{ Nama } & Nilai \\
\hline 1. & Seni & 90 \\
\hline 2. & Alya Humairah & 85 \\
\hline 3. & Gevani Aurel & 90 \\
\hline 4. & Arief Rahman & 90 \\
\hline 5. & Diva Naura & 85 \\
\hline 6. & Jeni Martin & 85 \\
\hline 7. & Miciata R. & 85 \\
\hline 8. & Tri Kurnia Ramadhani & 90 \\
\hline 9. & Fadhil Azikra & 80 \\
\hline 10. & Meilino Azikra & 90
\end{tabular}

\section{SIMPULAN}

Berdasarkan pelaksanan pelatihan penjelasan materi dan pembahasan sola ujian yang terdapat dalam program bazar ilmu dengan metode mind map di Tanah Ombak, pada bulan Maret 2018 maka dapat disimpulkan beberapa permasalahan, yaitu:

1. Melalui program bazar ilmu dengan metode mind map memberi kebebasan kepada anak untuk membahas dan mepertanyakan kepada instruktur tentang 
sisi kesulitan yang mereka rasakan sehingga proses pembelajaran lebih santai karena anak-anak tidak merasa terbebani.

2. Di samping itu, konsep pembelajaran "belajar sambil bermain" juga terintegrasi selama proses pelatihan berlangsung. Hal tersebut dikarenakan instruktur mengupayakan agar proses pembelajaran tidak monoton, tanpa tekanan, dan paksaaan yang mungkin dalam proses Belajar Mengajar di sekolah mereka rasakan. Dengan demikian, antusias anak sangat terlihat pada saat pelatihan berlangsung. Anak tidak ragu-ragu untuk mempertanyakan jika ada hal-hal yang tidak mereka pahami dan saling mendahului untuk menjawab pertanyaa-pertanyaan yang diberikan.

3. Melalui program kegiatan bazar ilmu dengan menggunakan metode mind map juga berdampak pada perolehan nilai siswa ketika menjawab soal-soal yang diberikan setelah penjelasan materi. Hal tersebut disebabkan adanya iklim pembelajaran yang sangat santai dan siswa tidak merasa terbebani dalam pembelajaran.

\section{DAFTAR PUSTAKA}

BPS. 2014. Luas Daerah dan Jumlah Penduduk Kota Padang. Dalam www.sumbar.bps.go.id. diunduh 23 Mei 2016.

De Porter, B dan Hernacki, M. 2008. Quantum Learning: Membiasakan Belajar Nyaman dan Menyenangkan. Bandung: Kaifa.

Imansyah, N. 2016. Anggota DPR sebut minat baca penduduk Indonesia rendah. News. Dalam http://www.antaranews.com/berita/556186/anggota-dpr-sebutminat-baca-penduduk-indonesia-rendah. Diunduh 18 Mei 2016.

Suhariyanto, K. 2015. Indeks Pembangunan Manusia (IPM):(Metode Baru). Dalam http://www.bps.go.id/website/pdf_publikasi/Bahan-Sosialisasi-IPMMetode-Baru.pdf. Diunduh 18 Mei 2016. 